\title{
Empirical Analysis of Financial Development Institutions and Economic Growth in Tanzania: Based on ARDL Model
}

\author{
Hamis Mirai Ally SIMBA (iD) a Erhan ÇANKAL iD $b$ \\ a Ankara Yildirim Beyazit University, Faculty of Political Science, Department of Economics, Ankara, Turkey. mirajihamisi@gmail.com \\ b Ankara Yildirim Beyazit University, Business School, Department of Banking and Finance, Ankara, Turkey.ecankal@ybu.edu.tr
}

\begin{tabular}{|c|c|}
\hline ARTICLE INFO & ABSTRACT \\
\hline $\begin{array}{l}\text { Keywords: } \\
\text { Tanzania, }\end{array}$ & $\begin{array}{l}\text { Purpose - The financial institutions have a significant contribution to foster economic growth of a } \\
\text { country. This study has the intention to investigate the causal relationship between financial } \\
\text { development institutions and economic growth in Tanzania. }\end{array}$ \\
\hline $\begin{array}{l}\text { GDP, } \\
\text { ARDL, } \\
\text { Granger Causality }\end{array}$ & $\begin{array}{l}\text { Design/methodology/approach - The study spans from } 1989 \text { to } 2018 \text {. The article uses four proxy of } \\
\text { financial development institutions against Gross Domestic Product (GDP) growth (Annual \%). } \\
\text { Financial proxy of variables of development institutions comprises Broad Money (\% of GDP), } \\
\text { Domestic credit for private sector (\% of GDP), Domestic credit provided by financial sector (\% of } \\
\text { GDP), and Domestic credit to the private sector by banks ( } \% \text { of GDP). This study uses Autoregressive }\end{array}$ \\
\hline Received 19 March 2020 & Distributed Lag (ARDL), Vector Error Correction Model (VECM), and Granger Causality test. \\
\hline $\begin{array}{l}\text { Article Classification: } \\
\text { Research Article }\end{array}$ & $\begin{array}{l}\text { Findings - The paper tries to find the cointegration effects and causal relationships between the proxy } \\
\text { variables and economic growth in Tanzania. It indicates that the economic growth of Tanzania } \\
\text { dominates financial development institutions. Therefore, economic growth in Tanzania leads to the } \\
\text { growth of financial sector. The development of financial sector also gives way to rise in overall } \\
\text { economic activity. It is a unidirectional relationship through which the proxy variables depend on } \\
\text { economic growth in the country. }\end{array}$ \\
\hline & $\begin{array}{l}\text { Discussion - Tanzania government should invest more in the financial institutions in order to } \\
\text { improve the economic growth in Tanzania.. }\end{array}$ \\
\hline
\end{tabular}

\section{Introduction}

Financial development institution (FDI) and economic growth has drowned a great tension among the school of economics. The thought of schools, which are associated with the FDI and GDP, have been classified into two disciplines. The first thought is Classical school, which includes Goldsmith, (1969), Beck and Levine, R. (2000). Levin (1997), McKinnon (1973) and Schumpeter (1991) suggested that FDI is an essential factor for economic growth. FDI affects GDP due to the influence of saving, investment, technology, and innovations (Levine, 1999). Furthermore, the thought of neoclassical school of theorists argued, "FDI is not an essential tool for GDP" (Pack, 1994). Lucas argued that the rapport of FDI and GDP has overstressed in the long run. Furthermore, the FDI and GDP from the context of analysts like Anderson and Tarp (2003), De Groen (2017) Ayad, Arbak, and Grechyna (2015) gave their comments and evidence that explain the FDI is inversely proportional to the GDP. In addition to that, some of the current studies which are related to FDI and GDP illustrate the positive association between GDP and FDI (Levine and Loayza, 2000; Hristopoulos and Tsiana, 2004; Herwartz and Walle, 2014). The discussion about the correlation between FDI and GDP has traditionally brought about two questions. The first question is relating to whether development in the FDI system leads to an increase in GDP. The second question relates to how FDI affects GDP (King and Levin, 1993). Both theoretical and empirical investigations are being performed to answer those two questions. In the theoretical part, it responds by explaining that the relationship between GDP and FDI affects each other. Schumpeter has described a good example in the years of 1911, who highlighted the decisive role of FDI and GDP. Patrick's study argued that "the prosecution of hypotheses demand or the transmission of supply hypotheses could be established, in the side of hypothesis demand, and the demand for FDI depends on GDP (Patrick, 1966). The structure and extension of financial development institution, which is related to an increase in financial assets and its services, are results of depositors' and investor's requirements. In this condition, the extension of FDI

\section{Suggested Citation}

Simba, H.M.A., Çankal, E. (2020). Empirical Analysis of Financial Development Institutions and Economic Growth in Tanzania: Based on ARDL Model, Journal of Business Research-Turk, 12 (2), 1962-1973. 


\section{H. M. A. Simba - E. Çankal 12/2 (2020) 1962-1973}

is caused by GDP (Jung, W. S, 1986). In the supply side, which is identified as a guiding offer, the assumption depicts the FDI causes GDP to grow. The supplying hypothesis explains the conventional of leading supply theory assumption that" the trend of causal relationship moves from FDI towards GDP; accordingly, FDI affects GDP or GDP depends on FDI (Calderón and Liu, 2003). The better performance of the GDP of the state always depends on the creation and sustainability of a strong FDI. The strong FDI associated with intermediaries of financial marketing which exercise at a significant level on the total productivity of the GDP. Intermediaries are creating very substantial functions for the improvement of the FDI by reducing the costs of accessing information, transactions, monitoring and constructing a positive impact on GDP (Ang, 2008). Creane (2003) argued that. "the modern, well established financial systems in terms of the technology and best services, always encourage investors to invest; people can save by depositing a huge amount of the money on their accounts, creating network business opportunities through capitalizations, in doing so it leads to strength the GDP of the states. Therefore, the best financial roles create efficient results, better resource allocation, creations of job opportunities and advancement of technology and innovations which leads to an increase the GDP. Tsuru (2000) also argued that FDI could stimulate GDP by using efficiency capital productivity that leads to stimulate and converting the final resources into investment (Tsan. 2000). FDI is a progression that marks advanced the financial systems in terms of quantity, quality and intermediaries services.

Refer to the "endogenous economic growth" explains the relationship between FDI and GDP as the hypothesize that "savings directly influences equilibrium income per capita and growth rates" (Green,1990: Bencivenga and Smith, 1990). Hermes, from his investigation, argued that both theories of financial liberalization and the new growth explain about FDI leads to GDP (Hermes and Lensink, 2008). In addition to that, Murinde and Luitel in the years of 1994 and 1999 argued that the maximum level of endogenous growth indicates the bidirectional causal correlation between FDI and GDP. The discussion of directional causal rapport between FDI and GDP indicates that the relationship between FDI and GDP is the bidirectional causality conditions (Shan, Morris, Sun, 2001). The banking system, as the major instrument of formation and strengthening of the FDI, it has much positive impact on GDP, exceptionally well-practiced to the developing countries like Tanzania. George (2010) argued that the country systemized with large banks and the active stock market, its economic growth would be faster to compare to the fewer numbers of banks and stock markets. Generally, the strong banking system will have more effects on FDI as well as the GDP of the country. Therefore, industries, firms, and other types of investments that rely on FDI grows proportional faster in the countries that have well-developed banking systems and securities markets compare to the states which have less actively developed management financial systems (Holmes and Kent, 1991).

\section{Literature Review}

Academic scholars have a lot of debates regarding the correlation between FDI and GDP. Some of the schools argue that FDI causes GDP, while others argue that GDP leads to FDI or they depend on each other. Some state that GDP and FDI are negatively correlated. This literature discusses the arguments in terms of theoretical and empirical perspectives. Schumpeter (1911) argued that FDI is acting as the key element in GDP. The significance of FDI and GDP is due to the existence of technological innovation on financial markets and the financial banking system, which leads to efficiency of capital accumulation. The capital accumulation, which stands as capital investment, helps provide funds to the entrepreneurs, firms, industries, and financial intermediaries, which improve to raise the savings and investment rate. All of these functionalities have resulted in a better economic performance. In this case, FDI causes GDP.

Patrick (1966) suggested two assumptions that have been extended to the hypothesis. The hypothesis is well recognized as the supply leading and demand hypothesis. The hypothesis states that GDP of a country at early stages of development literally depends on FDI so that FDI causes GDP. The country once reaches its best economic performance and considered as a developed one then the growth creates demand for FDI. At this level, the economic growth can be ascribed to a well-designed financial system. Goldsmith (1969) found a significant relationship between FDI and GNP, and he argued that GDP has bidirectional feedback on financial market by producing an incentive that prospers FDI (Goldsmith, 1969). McKinnon and Shaw in 1973 and 1993 explained further about the Patrick's argument by notifying the financial deepening to represent higher capital productivity and saving rate, and they argued that both lead to higher investments. McKinnon (1973) and Shaw (1993) focused intensely on the policies towards the financial systems (Greenwood and Jovanovic, 1990). 


\section{H. M. A. Simba - E. Çankal 12/2 (2020) 1962-1973}

For instance, undesirable real interest rate leads to a reduction of savings, and in turn, may result in abated investments and GDP (Reinhart and Tokatlidis, 2005).

According to Greenwood and Jovanovic (1990), both FDI and GDP are endogenous. The theoretical framework of this model has incorporated and investigated the functions of FDI and long run effect of GDP formally. In this model, the mechanism of the FDI is to examine the information and distribute the funds to investments that will yield the maximum return. Greenwood and Jovanovic (1990) model shows a directional feedback relationship between GDP and FDI. The development of GDP further stimulates higher involvement of financial markets, which leads to the construction and expansion of FDI. The model presented by Bencivenga and Smith (1991) was revealed that growth trends tend to increase even if the cumulative savings are lowered the FDI.

Gregorio and Guidotti (1998) examined the association among proxy of FDI and GDP. In most states, the outcomes indicate the causal relationship between GDP and FDI. Levine (1997) argued that finance is the lubricant of the main engine of GDP (Gregorio, Guidotti, and Végh, 1998). The study by King and Levin (1993) investigated whether the finance system had the ability to create a growth in GDP. The study used panel data, which comprises 80 countries, for the period 1960-1989. The outcome of the study emphasized the impact of FDI on GDP. The research intended to examine the relationship between FDI and GDP, through which the system of finance uses the proxy variables as the ratio of BCPS and GDP (De Gregonorio and Guidott, 1995). In this research, about 100 national states including Latin America over the period 1960 to 1985 were included for the analyses. The results indicated positive impact to the proxy variables towards economic growth. However, it shows some adverse effects for Latin American countries once the panel data were applied. The research about financial intermediaries on real GDP was conducted by Odedokun (1996) that employs the annual data of 71 states from 1960 to 1980 . The research revealed that the intermediation of finance improved GDP in about $85 \%$ of the states, and the financial intermediation helped support the extension of exportation and capital formation, and labor force growth. Claassen (2005) argued that higher the interaction amongst banks, firms, and industries in the country, the faster the growth in finance sector. By using annual data Demetriades and Hussein (1996) revealed that most of the states have causality bidirectional relationship. Shan and Morris (2001) applied the VAR method to estimate the rapport between GDP and FDI for OECD countries, and the research revealed a bidirectional relationship between financial development institution and economic growth. The study emphasized that FDI leads to GDP, while Granger causality shows bidirectional relationships in the developing countries.

The research conducted by Douglass using cointegration and VECM in Africa to scrutinize the correlation between GDP and FDI in Sub-Saharan. GDP and FDI are connected in the long run about seven to eight countries such as South Africa, Togo, Senegal, Zambia, Ghana, Zambia, Nigeria, Kenya and Ivory Coast. The study revealed a unidirectional relationship move from FDI towards GDP. The research conducted by Michael (2001) to investigate the causal relation connected with financial capital accounting liberalization and economic liberalization, financial deepening, and GDP, using data cross sectional for the period of 1986 and 1995, which is associated with richest and poor countries. The outcome revealed a positive effect on capital towards financial depth and GDP. Choe and Moose (1999) inspected the relationship between GDP and FDI for1970-1992 period for South Korea. The research includes financial intermediaries, capital investment, the impact of the behavior of households and business sectors as the main key points. The causality was from FDI to GDP. The financial intermediaries seem to be stronger compared to capital markets. The panel data from the 74 countries for 1961-1995 period were tested by Rioja and Valev (2004). They used GMM and dynamic panel techniques. The result of this investigation revealed that FDI may affect productivity growth and accumulation of capital in various ways in industrialized and developing countries. Therefore, financial systems have a stronger positive impact in developed countries compare to developing countries. In addition to that FDI impacts GDP, which definitely occurs in the accumulation of capital (Rioja and Valey, 2004). The study conducted by Othiambo (2005), which includes proxy of FDI variables such as percentage of broad money against GDP, the percentage of currency to narrow the definition of cash and the ratio of bank claim in the private sector against the real GDP per capita. The research uses annual data based in Tanzania, which spanning the period 1960 to 2005 for identifying the unit root, Johansen-Junsellius test for cointegration, and VECM for the determination of long run and short run effect. The outcome indicates the bidirectional rapport between the proxy of financial and real GDP per capita (Odhiambo, N. M, 2005). Waqaba (2004) conducted a 


\section{H. M. A. Simba - E. Çankal 12/2 (2020) 1962-1973}

research by applying annual data for Fiji for $1970-2008$ period. The research investigated the cointegration and causal relationship between FDI and GDP. The result shows a relationship between GDP and FDI in Fiji, with causation running from GDP to FDI (Waqabaca, 2004). Othimbo (2007) studied the relationship between GDP and FDI using Granger causality for Sub-Sahara countries, including Tanzania, South Africa and Kenya for 1980-2005 period. The research found that the directional causality of the variables is very sensitive compared to the variables selected by Odhiambo (2008). Akinle and Egbetunde (2010) employed (Vector Error Correction Model (VECM) to examine long run relationship of causality among the GDP and FDI for ten countries of Sub -Saharan of Africa. The results showed that the long run FDI is integrated with GDP. The dynamic relationship between FDI and GDP was examined by Othiambo (2011) for 1980-2004 period using Granger causality and ARDL bound tests. The study uses capital inflows as the intermittent variables between FDI and GDP. The result indicates the causal unidirectional flows from financial depth towards economic growth. The causal bidirectional was revealed between FDI and foreign capital inflows and unidirectional flows from foreign capital inflows to GDP. Al-Naif (2012) applied Granger causality and VECM for annual data for 1977 to 2008 in Jordan to investigate the causal relationship between FDI and GDP. The research revealed the presence of both the long run and short-run correlation between FDI and GDP, and the unidirectional correlation directing from FDI towards GDP. According to the recent studies conducted by Herwartz and Walle (2014) for 1975-2011 period including 73 states, the impact of the FDI is strong in the reach states compared to that in the poor states with lower income economies. Another recent study conducted by Arvin, Pradhan, Bahman, Norman and Hall (2017), which uses four proxy variables of FDI, such as the baking and development sector, bond of market development, stock market development, and insurance market development sector, concluded that all the proxies were cointegrated in the long run. Most of the studies show how different thought of schools depict their thought related to FDI and GDP. The literature about FDI and GDP relationship does not demonstrate consensus in the results, but conflicts. There are some studies that support the theory of response of leading supply while some support the bidirectional causality. There is no consensus with regard to the causal directional relationship among the applicable variables. Generally, the countries have different structures in financial management systems, different level of GDP, and different proxy of FDI, which are applied to represent the functions and strength of FDI. Therefore, the research has the inspiration to investigate the causal directional relationship between GDP and FDI in Tanzania.

\section{Methodology}

The research uses the data on annual GDP growth, the proxy of financial development institution (FDI) that comprises of broad money, domestic credit private sectors, private and financial sectors. The data are extracted from World Bank Development Indicators (WBDI) over the period 1989-2018. Broad money is considered as one of the proxies of FDI. The circulation of more money in an economic system implies that the accessibility of the currency in the financial systems is very high, which leads to expansions of business and trade in communities. On the other hand, circulating fewer money may lead to a reduction of money on the hands of economic agents. This situation may cause shut down some of the economic units in an economy and give a way to economic crisis.

Broad Money (BM) is an entity which can be defined by Central Banks to measure and controlling any interventions because it leads the economy to expand or contract: The second proxy variable of FDI is Domestic Credit provided by Banking Sector (DCBS). It is the kind of financial resources, which is given to the private sectors by other corporations of depository. The action of deposit generally is being provided by the corporations and not for central banks. Such a deposit is mostly being applied, by purchasing securities of inequities, through loans, credit trades, and some of the other receivable accounts which have been established by repayment of the claim. The third proxy of FDI is Domestic Credit to Financial Sectors (DCFS) in which contains credit in different sectors regarding the gross basis. It does not include the net credit from the Central Bank. It consists of the authority of the monetary system, banking system, and financial corporations, which refuse transferrable deposit and incur liabilities like saving deposits and time. The fourth proxy of FDI is Domestic Credit of Private Sector (DCPS) in which is referred to as the financial entity that is given to the private sectors by the corporation of finance.

Rao (2008) argued that the correlation of GDP and FDI can be derived from a modification of Solow model production function (1956), which has constant return to scale and steady technical progress as referred from the Hicks (Rao,2008). 
$\mathrm{Y}_{\mathrm{t}}=\mathrm{A}_{\mathrm{t}} \mathrm{K}_{\mathrm{t}}^{\alpha} \quad 0<\alpha<1$

meaning that $Y_{t}$ represent the economic growth (GDP), $A_{t}$ stands for technological advancement, and $K_{t}$ represents capital investment. The technological advancement $A_{t}$ grows exponentially (at rthe rate of g) over time that can be expressed as

$\mathrm{A}_{\mathrm{t}}=\mathrm{A}_{0} e^{g t}$

where $A_{0}$ is the initial technological level. Rao assumes that $A_{t}$ is the function of the financial development institution $\mathrm{FDI}_{\mathrm{t}}$. Thus, the equation above can be represented as

$A_{t}=f\left(t, F D I_{t}\right)$

where $t$ and $\mathrm{FDI}_{\mathrm{t}}>0$

Thus, the equation is modified and expressed as

$\mathrm{A}_{\mathrm{t}}=\mathrm{A}_{0} e^{g t} \mathrm{FDI}_{\mathrm{t}}^{\beta}$

The equation (2) can be substituted into the equation (4)

$\mathrm{Y}_{\mathrm{t}}=\left(\mathrm{A}_{0} e^{g t} \mathrm{FDI}_{\mathrm{t}}^{\beta}\right) \mathrm{K}_{\mathrm{t}}^{\alpha}$.

Furthermore, this equation can be written in linear form and be expressed as

$\ln Y_{t}=\ln A_{0}+g t+\beta_{t} \operatorname{lnFDI} I_{t}+\alpha \ln K_{t}$

However, the research is related to proxy variables of FDI and GDP, and therefore the variables of ' $\mathrm{gt}^{\prime}$ ' and. ' $\mathrm{K}_{\mathrm{t}}{ }^{\prime}$ are ignored and the equation above is expressed as the

$\ln Y_{t}=\ln A_{0}+\beta_{t} \operatorname{lnFDI} I_{t}$

but $\mathrm{FDI}_{\mathrm{t}}$ represent the proxy variables of financial development institutions such as BM, DCBS, DCPS, and DCFS, and $\ln A_{0}$ is referred to as the constant. Therefore, the modified equation can be expressed as

$\operatorname{lnGDP}_{t}=C_{0}+\beta_{1} \operatorname{lnBM}_{t}+\beta_{2} \operatorname{lnDCPS}_{t}+\beta_{3} \operatorname{lnDCBS}_{t}+\beta_{3} \operatorname{lnDCFS}_{\mathrm{t}}$

The "ln" represents the natural logarithm, $Y_{t}$ replaced by GDP, which represents the economic growth of Tanzania, $\beta$ represent the coefficients (parameters) related to the specific explanatory variables, while BM is the Broad Money, DCPS is domestic credit of private sectors, DCBS represents the domestic credit of private sectors associated with Banks, BCFS domestic credit to financial sectors and $\mathrm{C}_{0}$ is the intercept of the model.

According to the classical assumption associated with the unit root diagnosis, the variables should have constant, mean, variance, and covariance. The violation of this assumption may lead us to have spurious regression. Therefore, the problem of spurious regression should be detected and avoided by testing the variable and to find its order of stationarity. When non-stationary is detected, the stationary is induced by taking the first difference or second difference of specific variable. The ADF is used to determine the stationary or nonstationary conditions of the variable. The order of integration expresses the level of stationarity of the variable. Therefore, the order of integration can be occurring at level, at first difference level, and second difference level, and so on. In the analysis, the order of integration is being identified by using Augmented Dickey-Fuller (ADF), Dickey-Fuller - Generalized Least Square (DF-GLS) and Phillip-Perron (PP) tests.

This study uses Auto Regressive Distributed Lag (ARDL) because it is different from Engle and Granger or Johansen cointegration test. Johansen or Engel and Granger prefer the variables to integrate at the same order of stationary. The integration of the order exists, either at level, at first level, second level or third level. But the ARDL method is free of pretesting problems accompanying the order of integration in such a way that the prestige of integration includes at first difference and level but not at second difference. The ARDL possesses the following criteria; first, the ARDL identifies long run and short run effect, Secondly, ARDL is more applied to the small sample size in such a way that the estimators of OLS which define consistency of short run parameters and estimators' ARDL which are based in the coefficients of long run are super consistent in small sample sizes. Another important point, the ARDL is free from the problem of endogeneity, which affects Engel and Granger (Harris and Sollik, 2003). The first step is the endurance of the presence of cointegration from 
H. M. A. Simba - E. Çankal 12/2 (2020) 1962-1973

OLS. The intention to assess the equations is to understand the presence of the long run and short-run between the proxy of FDI and GDP with respect to the particular equation. To implement the ARDL for finding the cointegration effect among the variables can be represented as follows:

$\Delta \operatorname{lnGDP} P_{\mathrm{t}}=\mathrm{C}_{0}+\sum_{\mathrm{k}=1}^{\mathrm{n}} \beta_{1 \mathrm{k}} \Delta \operatorname{lnGDP}_{\mathrm{t}-\mathrm{i}}+\sum_{\mathrm{i}=1}^{\mathrm{n}} \beta_{1 \mathrm{k}} \Delta \operatorname{lnBM}_{\mathrm{t}-\mathrm{i}}+\sum_{\mathrm{i}=1}^{\mathrm{n}} \beta_{3 \mathrm{k}} \Delta \operatorname{lnDCPS}_{\mathrm{t}-\mathrm{i}}+\sum_{\mathrm{i}=1}^{\mathrm{r}} \beta_{4 \mathrm{k}} \Delta \operatorname{lnDCBS}_{, \mathrm{t}-\mathrm{i}}+$ $\sum_{\mathrm{i}=1}^{\mathrm{r}} \beta_{1 \mathrm{k}} \Delta \operatorname{lnDCFS}{ }_{\mathrm{t}-\mathrm{i}}+\delta_{1} \operatorname{lnGDP}_{\mathrm{t}-1}+\delta_{2} \operatorname{lnBM}_{\mathrm{t}-1}+\delta_{3} \operatorname{lnDCPS}_{\mathrm{t}-1}+\delta_{4} \operatorname{lnDCBS}_{\mathrm{t}-1}+\delta_{5} \operatorname{lnDCFS}_{\mathrm{t}-1}+\varepsilon_{1 \mathrm{t}}$

$\Delta \operatorname{lnBM} M_{\mathrm{t}}=\mathrm{C}_{0}+\sum_{\mathrm{i}=1}^{\mathrm{n}} \beta_{1 \mathrm{k}} \Delta \operatorname{lnBM} \mathrm{t}_{\mathrm{t}-\mathrm{i}}+\sum_{\mathrm{k}=1}^{\mathrm{n}} \beta_{2 \mathrm{k}} \Delta \mathrm{lGDP}_{\mathrm{t}-\mathrm{i}}+\sum_{\mathrm{i}=1}^{\mathrm{n}} \beta_{3 \mathrm{k}} \Delta \operatorname{lnDCPS}_{\mathrm{t}-\mathrm{i}}+\sum_{\mathrm{i}=1}^{\mathrm{r}} \beta_{4 \mathrm{k}} \Delta \operatorname{lnDCBS} \mathrm{t}_{\mathrm{t}-\mathrm{i}}+$ $\sum_{\mathrm{i}=1}^{\mathrm{r}} \beta_{1 \mathrm{k}} \Delta \operatorname{lnDCFS}{ }_{\mathrm{t}-\mathrm{i}}+\delta_{1} \operatorname{lnGDP}_{\mathrm{t}-1}+\delta_{2} \operatorname{lnBM}_{\mathrm{t}-1}+\delta_{3} \operatorname{lnDCPS}_{\mathrm{t}-1}+\delta_{4} \operatorname{lnDCBS}_{\mathrm{t}-1}+\delta_{5} \operatorname{lnDCFS}_{\mathrm{t}-1}+\varepsilon_{2 \mathrm{t}}$

$\Delta \operatorname{lnDCPS}{ }_{\mathrm{t}}=\mathrm{C}_{0}+\sum_{\mathrm{i}=1}^{\mathrm{n}} \beta_{1 \mathrm{k}} \Delta \operatorname{lnDCPS} \mathrm{t}_{\mathrm{t}-\mathrm{i}}+\sum_{\mathrm{i}=1}^{\mathrm{n}} \beta_{2 \mathrm{k}} \Delta \operatorname{lnBM} \mathrm{t}_{\mathrm{t}-\mathrm{i}}+\sum_{\mathrm{k}=1}^{\mathrm{n}} \beta_{3 \mathrm{k}} \Delta \operatorname{lnGDP}_{\mathrm{t}-\mathrm{i}}+\sum_{\mathrm{i}=1}^{\mathrm{r}} \beta_{4 \mathrm{k}} \Delta \operatorname{lnDCBS}_{, \mathrm{t}-\mathrm{i}}+$ $\sum_{\mathrm{i}=1}^{\mathrm{r}} \beta_{1 \mathrm{k}} \Delta \operatorname{lnDCFS}_{\mathrm{t}-\mathrm{i}}+\delta_{1} \operatorname{lnGDP}_{\mathrm{t}-1}+\delta_{2} \operatorname{lnBM}_{\mathrm{t}-1}+\delta_{3} \operatorname{lnDCPS}_{\mathrm{t}-1}+\delta_{4} \operatorname{lnDCBS}_{\mathrm{t}-1}+\delta_{5} \operatorname{lnDCFS}_{\mathrm{t}-1}+\varepsilon_{3 \mathrm{t}}$

$\Delta \operatorname{lnDCBS}_{\mathrm{t}}=\mathrm{C}_{0}+\sum_{\mathrm{i}=1}^{\mathrm{r}} \beta_{1 \mathrm{k}} \Delta \operatorname{lnDCBS}_{\mathrm{t}-\mathrm{i}}++\sum_{\mathrm{i}=1}^{\mathrm{n}} \beta_{2 \mathrm{k}} \Delta \ln \operatorname{lnCPS}_{\mathrm{t}-\mathrm{i}}+\sum_{\mathrm{i}=1}^{\mathrm{n}} \beta_{3 \mathrm{k}} \Delta \operatorname{lnBM}_{\mathrm{t}-\mathrm{i}}+\sum_{\mathrm{k}=1}^{\mathrm{n}} \beta_{4 \mathrm{k}} \Delta \operatorname{lnGDP}_{\mathrm{t}-\mathrm{i}}+$ $\sum_{\mathrm{i}=1}^{\mathrm{r}} \beta_{1 \mathrm{k}} \Delta \operatorname{lnDCFS}_{\mathrm{t}-\mathrm{i}}+\delta_{1} \operatorname{lnGDP}_{\mathrm{t}-1}+\delta_{2} \operatorname{lnBM}_{\mathrm{t}-1}+\delta_{3} \operatorname{lnDCPS}_{\mathrm{t}-1}+\delta_{4} \operatorname{lnDCBS}_{\mathrm{t}-1}+\delta_{5} \operatorname{lnDCFS}_{\mathrm{t}-1}+\varepsilon_{4 \mathrm{t}}$

$\Delta \operatorname{lnDCFS}_{\mathrm{t}}=\mathrm{C}_{0}+\sum_{\mathrm{i}=1}^{\mathrm{r}} \beta_{1 \mathrm{k}} \Delta \operatorname{lnDCF}_{S, \mathrm{t}-\mathrm{i}}+\sum_{\mathrm{i}=1}^{\mathrm{n}} \beta_{2 \mathrm{k}} \Delta \operatorname{lnDCPS}_{\mathrm{t}-\mathrm{i}}+\sum_{\mathrm{i}=1}^{\mathrm{n}} \beta_{3 \mathrm{k}} \Delta \operatorname{lnBM}_{\mathrm{t}-\mathrm{i}}+\sum_{\mathrm{k}=1}^{\mathrm{n}} \beta_{4 \mathrm{k}} \Delta \operatorname{lnGDP}_{\mathrm{t}-\mathrm{i}}+$ $\sum_{\mathrm{i}=1}^{\mathrm{r}} \beta_{1 \mathrm{k}} \Delta \operatorname{lnDCBS}_{, \mathrm{t}-\mathrm{i}}+\delta_{1} \operatorname{lnGDP}_{\mathrm{t}-1}+\delta_{2} \operatorname{lnBM}_{\mathrm{t}-1}+\delta_{3} \operatorname{lnDCPS}_{\mathrm{t}-1}+\delta_{4} \operatorname{lnDCBS}_{\mathrm{t}-1}+\delta_{5} \operatorname{lnDCFS}_{\mathrm{t}-1}+\varepsilon_{4 \mathrm{t}}$

The cointegration test is nonstationary of annual data, which possesses the variances and means which differ over time. Also, the cointegration can be defined as the system through which the equilibrium or long run of the variables are estimated once a data are being discovered or identified to be stationary states (Rao, 2007). The condition of data to be cointegrated represents the sign of the availability of long run effects on the provided variables. Therefore, once the long run effect is found, then the model will use the ECM to find the disequilibrium of the model, but when there is more than one equation that has been cointegrated, then the VECM is useful whereas cointegration point can be identified. The presence of negative sign, which has the probability less than $5 \%$ shows that the model is cointegrated. The positive sign of speed of adjustment or error correction technic revealed that the model is not cointegrated, but it represents the short-run effect. The cointegrated equation can be shown as follows:

$\Delta \operatorname{lnGDP}{ }_{\mathrm{t}}=\mathrm{C}_{0}+\sum_{\mathrm{k}=1}^{\mathrm{n}} \beta_{1 \mathrm{k}} \Delta \operatorname{lnGDP}_{\mathrm{t}-\mathrm{i}}+\sum_{\mathrm{i}=1}^{\mathrm{n}} \beta_{1 \mathrm{k}} \Delta \operatorname{lnBM}_{\mathrm{t}-\mathrm{i}}+\sum_{\mathrm{i}=1}^{\mathrm{n}} \beta_{3 \mathrm{k}} \Delta \operatorname{lnDCPS}_{\mathrm{t}-\mathrm{i}}+\sum_{\mathrm{i}=1}^{\mathrm{r}} \beta_{4 \mathrm{k}} \Delta \operatorname{lnDCBS}_{, \mathrm{t}-\mathrm{i}}+$ $\sum_{\mathrm{i}=1}^{\mathrm{r}} \beta_{1 \mathrm{k}} \Delta \operatorname{lnDCFS}_{\mathrm{t}-\mathrm{i}}+\operatorname{lnDCPS}_{\mathrm{t}-\mathrm{i}}+\lambda \mathrm{ECT}_{\mathrm{t}-1}+\varepsilon_{5 \mathrm{t}}$

$\Delta \operatorname{lnBM}_{\mathrm{t}}=\mathrm{C}_{0}+\sum_{\mathrm{i}=1}^{\mathrm{n}} \beta_{1 \mathrm{k}} \Delta \operatorname{lnBM}_{\mathrm{t}-\mathrm{i}}+\sum_{\mathrm{k}=1}^{\mathrm{n}} \beta_{2 \mathrm{k}} \Delta \mathrm{lGDP}_{\mathrm{t}-\mathrm{i}}+\sum_{\mathrm{i}=1}^{\mathrm{n}} \beta_{3 \mathrm{k}} \Delta \operatorname{lnDCPS} \mathrm{t}_{\mathrm{t}-\mathrm{i}}+\sum_{\mathrm{i}=1}^{\mathrm{r}} \beta_{4 \mathrm{k}} \Delta \operatorname{lnDCBS}_{\mathrm{t}-\mathrm{i}}+\sum_{\mathrm{i}=1}^{\mathrm{r}} \beta_{1 \mathrm{k}} \Delta \ln \operatorname{lnCFS}_{\mathrm{t}-\mathrm{i}}$ $+\lambda \mathrm{ECT}_{\mathrm{t}-1}+\varepsilon_{6 \mathrm{t}}$

$\Delta \operatorname{lnDCBS}_{\mathrm{t}}=\mathrm{C}_{0}+\sum_{\mathrm{i}=1}^{\mathrm{r}} \beta_{1 \mathrm{k}} \Delta \operatorname{lnDCBS}_{\mathrm{t}-\mathrm{i}}++\sum_{\mathrm{i}=1}^{\mathrm{n}} \beta_{2 \mathrm{k}} \Delta \operatorname{lnDCPS} \mathrm{t}_{\mathrm{t}-\mathrm{i}}+\sum_{\mathrm{i}=1}^{\mathrm{n}} \beta_{3 \mathrm{k}} \Delta \operatorname{lnBM}_{\mathrm{t}-\mathrm{i}}+\sum_{\mathrm{k}=1}^{\mathrm{n}} \beta_{4 \mathrm{k}} \Delta \operatorname{lnGDP} \mathrm{t}_{\mathrm{t}-\mathrm{i}}+$ $\sum_{\mathrm{i}=1}^{\mathrm{r}} \beta_{1 \mathrm{k}} \Delta \operatorname{lnDCFS}, \mathrm{t}-\mathrm{i}+\lambda \mathrm{ECT}_{\mathrm{t}-1}+\varepsilon_{6 \mathrm{t}}$

$\Delta \operatorname{lnDCFS}_{\mathrm{t}}=\mathrm{C}_{0}+\sum_{\mathrm{i}=1}^{\mathrm{r}} \beta_{1 \mathrm{k}} \Delta \operatorname{lnDCF}_{S, \mathrm{t}-\mathrm{i}}+\sum_{\mathrm{i}=1}^{\mathrm{n}} \beta_{2 \mathrm{k}} \Delta \operatorname{lnDCPS}_{\mathrm{t}-\mathrm{i}}+\sum_{\mathrm{i}=1}^{\mathrm{n}} \beta_{3 \mathrm{k}} \Delta \operatorname{lnBM}_{\mathrm{t}-\mathrm{i}}+\sum_{\mathrm{k}=1}^{\mathrm{n}} \beta_{4 \mathrm{k}} \Delta \operatorname{lnGDP}_{\mathrm{t}-\mathrm{i}}+$ $\sum_{\mathrm{i}=1}^{\mathrm{r}} \beta_{1 \mathrm{k}} \Delta \ln \mathrm{lnCBS}, \mathrm{t}-\mathrm{i}+\lambda \mathrm{ECT}_{\mathrm{t}-1}+\varepsilon_{7 \mathrm{t}}$

$\Delta \operatorname{lnDCPS}_{\mathrm{t}}=\mathrm{C}_{0}+\sum_{\mathrm{i}=1}^{\mathrm{n}} \beta_{1 \mathrm{k}} \Delta \operatorname{lnDCPS}_{\mathrm{t}-\mathrm{i}}+\sum_{\mathrm{i}=1}^{\mathrm{n}} \beta_{2 \mathrm{k}} \Delta \operatorname{lnBM}_{\mathrm{t}-\mathrm{i}}+\sum_{\mathrm{k}=1}^{\mathrm{n}} \beta_{3 \mathrm{k}} \Delta \operatorname{lnGDP}_{\mathrm{t}-\mathrm{i}}+\sum_{\mathrm{i}=1}^{\mathrm{r}} \beta_{4 \mathrm{k}} \Delta \operatorname{lnDCBS}{ }_{, \mathrm{t}-\mathrm{i}}+$ $\sum_{\mathrm{i}=1}^{\mathrm{r}} \beta_{1 \mathrm{k}} \Delta \ln \operatorname{lnCFS}_{\mathrm{t}-\mathrm{i}}+\lambda \mathrm{ECT}_{\mathrm{t}-1}+\varepsilon_{6 \mathrm{t}}$

In general, the indication of the cointegration process goes together with the high rate of the possibility of a causal correlation between GDP and FDI. Thus, the presence of cointegration needs error correction for adjusting of disequilibrium of that variable. The existence of error correction implies the change in the dependent as the function of disequilibrium in the cointegration between ECT and the change in the other exogenous variable(s). The mechanism of cointegration, which found to be cointegrated at either $\triangle \mathrm{GDP}_{\mathrm{t}}$ or $\Delta \mathrm{FDI}_{\mathrm{t}}$ alternatively, must be caused by lagged ECT that is a function of $\mathrm{GDP}_{1-\mathrm{t}}$, and $\mathrm{FDI}_{1-\mathrm{t}}$.

$\Delta \operatorname{lnGDP}_{\mathrm{t}}=\mathrm{C}_{1}+\sum_{\mathrm{j}=1}^{\mathrm{m}} \theta_{1 \mathrm{j}} \Delta \operatorname{inGDP}_{\mathrm{t}-1}+\sum_{\mathrm{j}=1}^{\mathrm{n}} \delta_{1 \mathrm{j}} \Delta \operatorname{lnFDI}_{\mathrm{j}=1}+\sum_{\mathrm{j}=1}^{\mathrm{k}} \delta_{1 \mathrm{j}} \mathrm{ECM}_{\mathrm{j}=1}+\mathrm{U}_{\mathrm{t}}$
$\Delta \operatorname{lnFDI}_{\mathrm{t}}=\mathrm{C}_{2}+\sum_{\mathrm{j}=1}^{\mathrm{m}} \delta_{2 \mathrm{j}} \Delta \operatorname{lnGDP} \mathrm{j}_{\mathrm{j}=1}+\sum_{\mathrm{j}=1}^{\mathrm{n}} \theta_{2 \mathrm{j}} \Delta \operatorname{lnFDI}_{\mathrm{t}-1}+\sum_{\mathrm{j}=1}^{\mathrm{k}} \delta_{2 \mathrm{j}} \mathrm{ECM}_{\mathrm{j}=1}+\mathrm{U}_{\mathrm{t}}$ 


\section{H. M. A. Simba - E. Çankal 12/2 (2020) 1962-1973}

Where $\Delta$ represents the first difference from the nonstationary variable, $\theta$ and $\delta$ are parameters that need to be tested, $C_{t}$ is constant, and $U_{t}$ is an error term. At the end of the test, we would be able to check whether it is unidirectional causality or bidirectional causality (or feedback). The equation model above contains VECM, which can be the source of causation, which expresses the statistical importance of the three different tests (Charemza and Deadman, 1997). For example, the null hypothesis state that FDI do not Granger causes GDP, and this hypothesis is being refused if $\beta_{1 \mathrm{j}}$ different from zero. Again the same null hypothesis is ignored if $\delta_{1 \mathrm{j}}$ or $\beta_{1 \mathrm{j}}$ and $\delta_{1 \mathrm{j}}$ are significantly joint from zero. If long run effects are not found between FDI and GDP, then the causal of traditional tests can be used. One of the drawbacks is that the tests convert stationary data automatically by taking the differentiation of FDI and GDP, and therefore, it tends to remove the information about long run effects, which is originated on the GDP and FDI. The ECTM is obtained from the derivation of the equation of cointegrations by a corporation with its lags.

\section{Estimated Results and Discussion}

This part is characterized by the outcomes, and explains the econometrical interpretations associated with data analysis from the appropriate model. It comprises presentations of descriptive data for all variables, which include in the econometric tools like, ARDL, VECM, and Granger Causality, and is ending with post estimation results. The Breusch-Pagan-Godfrey test is performed in order to test for heteroscedasticity and proved to be homoscedastic. The annual time series data with natural logarithmic form are introduced in Table 1 and Table 2. The aims of the tables are to identify the integration of FDI and GDP concerning their order. Both Tables 1 and 2 show that both GDP and FDI are integrated at the level and first difference, meaning that the GDP and FDI are stationary at a level and first difference. ARDL accepts the condition once the GDP and FDI are integrated at the level and the first difference but not at the second difference. If the FDI and GDP are found to be stationary at I(0) and I(1), it allows us to proceed by estimating the cointegration effect.

\section{Table 1: Unit Root Test at Level}

\begin{tabular}{|c|c|c|c|c|c|c|c|}
\hline Variables & Augmen & Dic & y-Fuller $(A$ & & Phillips-1 & (PP) & \\
\hline & AIC lag & level & t-statistic & Prob & AIC lag & t-statistic & p-values \\
\hline $\operatorname{lnGDP}$ & 1 & $\mathrm{I}(0)$ & -3.1553 & $0.0125^{*}$ & 1 & -3.1622 & 0.1861 \\
\hline $\operatorname{lnBM}$ & 1 & $\mathrm{I}(0)$ & -3.0112 & $0.0456^{*}$ & 1 & -2.2134 & 0.2059 \\
\hline $\operatorname{lnDCBS}$ & 1 & $\mathrm{I}(0)$ & -3.7116 & $0.0090^{*}$ & 1 & -3.7305 & 0.0086 \\
\hline $\operatorname{lnDCPS}$ & 1 & $\mathrm{I}(0)$ & -3.7116 & $0.0090^{*}$ & 1 & -3.7305 & 0.0086 \\
\hline $\operatorname{lnDCFS}$ & 1 & $\mathrm{I}(0)$ & -3.0112 & $0.0456^{*}$ & 1 & -2.2134 & 0.0059 \\
\hline
\end{tabular}

*intercept, ${ }^{* *}$ intercept and trend

Table 2: Unit Root at First Difference

\begin{tabular}{|l|l|l|l|l|l|l|l|}
\hline Variables & ADF & PP \\
\hline &, lag & level & t-statistic & Prob & AIC lag & t-statistic & p-values \\
\hline $\ln$ GDP & 1 & $\mathrm{I}(1)$ & -5.742819 & $0.0003^{* *}$ & 1 & -6.817785 & 0.0000 \\
\hline $\ln B M$ & 1 & $\mathrm{I}(1)$ & -2.933504 & $0.0537^{*}$ & 2 & -3.040522 & 0.0428 \\
\hline $\ln \mathrm{CCBS}$ & 1 & $\mathrm{I}(1)$ & -10.91302 & $0.0000^{*}$ & 1 & -10.24759 & 0.0000 \\
\hline $\ln \mathrm{DCPS}$ & 1 & $\mathrm{I}(1)$ & -11.08089 & $0.0000^{*}$ & 1 & -10.24759 & 0.0000 \\
\hline $\ln \mathrm{DCFS}$ & 1 & $\mathrm{I}(1)$ & -2.933504 & $0.0537^{*}$ & 2 & -3.040522 & 0.0428 \\
\hline
\end{tabular}

*intercept, ${ }^{* *}$ intercept and trend

Table 3 shows that all proxies of FDI and GDP are observed to be at the upper bound test, which indicates GDP and FDI are cointegrated. The cointegration process of FDI and GDP has a long run effect. The choosing of ARDL is associated with lag1 and lag2, which includes AIC and SBC, as shown in Table 3. 
H. M. A. Simba - E. Çankal 12/2 (2020) 1962-1973

Table 3: Bond F-test for Cointegration

\begin{tabular}{|l|l|l|l|l|l|l|}
\hline \multirow{2}{*}{$\begin{array}{l}\text { Dependent } \\
\text { Variable }\end{array}$} & \multirow{2}{*}{ AIC lag } & \multirow{2}{*}{ F-statistc } & \multicolumn{2}{|l|}{ The boundary at 5\% } & \multirow{2}{*}{ Cointegration } & What is next \\
\cline { 4 - 7 } & & & $\mathrm{I}(0)$ & $\mathrm{I}(1)$ & & \\
\hline$\Delta \operatorname{lnGDP}_{\mathrm{t}}$ & 2 & 4.6309 & 2.86 & 4.01 & Yes & Estimate ECM \\
\hline$\Delta \operatorname{lnBM}_{\mathrm{t}}$ & 1 & 7.1283 & 2.86 & 4.01 & Yes & Estimate ECM \\
\hline$\Delta \operatorname{lnDCBS}_{\mathrm{t}}$ & 2 & 6.9028 & 2.86 & 4.01 & Yes & Estimate ECM \\
\hline$\Delta \operatorname{lnDCPS}_{\mathrm{t}}$ & 1 & 6.8159 & 2.86 & 4.01 & Yes & Estimate ECM \\
\hline$\Delta \operatorname{lnDCFS}_{\mathrm{t}}$ & 1 & 8.0525 & 2.86 & 4.01 & Yes & Estimate ECM \\
\hline
\end{tabular}

Table 3 represents the cointegration of the proxies of FDI and GDP. The ARDL bound test as an econometric tool has been applied to define the cointegration of applied variables. It uses the lower and upper bound test estimation to identify the presence or absence of cointegration. When F-stat is larger than upper bond, it identifies the presence of cointegration effect, but when the F_stat is found to be less than lower bound, it indicates that "there is no cointegration effect between FDI and GDP in the model. When F_stat is found to be existed within the upper and lower bonds test, it represents inconvenience condition. The assumption is calculated as the lower bound test with order zero, the upper bound test with the first order, and the values found in between representing that the F-statistic is an inconvenience.

Table 4 includes cointegration values from the estimated variables. It shows that all variables are cointegrated and significant at least at 0.05 level, except the DCPS, which does not show the cointegration effect. When the FDI and GDP are cointegrated, then the cointegration effect can be estimated.

Table 4: Cointegration

\begin{tabular}{|l|l|l|l|l|}
\hline Dependent Variable & AIC lag & ECT (speed of adjustment) & Probability & Status \\
\hline$\Delta \operatorname{lnGDP}$ & 1 & -0.168749 & 0.0181 & Significant \\
\hline$\Delta \operatorname{lnMB}$ & 2 & -0.316741 & 0.0728 & Significant \\
\hline$\Delta \ln$ DCBS & 1 & -0.423739 & 0.8679 & Not significant \\
\hline$\Delta \ln$ DCPS & 2 & -0.382517 & 0.9069 & Not significant \\
\hline$\Delta \operatorname{lnDCFS}$ & 1 & -0.299129 & 0.0175 & Significant \\
\hline
\end{tabular}

Table 5 represents a diagnosis of the rapport of GDP and FDI. The Classical Granger, which is related to the Wald test has been applied to determine the correlation among the GDP and proxies of FDI. The estimation results shown in Table 5 demonstrates the causal relationship between GDP and MB.

Table 5: The Individual Source of Causation using the Wald Test

\begin{tabular}{|c|c|c|c|c|}
\hline \multirow{2}{*}{$\begin{array}{l}\text { Dependent } \\
\text { Variable } \\
\end{array}$} & \multicolumn{2}{|l|}{ Wald Test } & \multirow{2}{*}{$\begin{array}{l}\text { t-test } \\
\text { ECM }_{-1}\end{array}$} & \multirow{2}{*}{$\begin{array}{l}\text { Joint Wald Test } \\
\left(\sum \Delta \ln \mathrm{MB}, \mathrm{ECM}_{-1}\right)\end{array}$} \\
\hline & $\sum \Delta \operatorname{lnGDP}$ & $\sum \Delta \ln M B$ & & \\
\hline$\Delta \operatorname{lnGDP}$ & & $\begin{array}{l}X^{2}(1)=0.0125 \\
(0.911)\end{array}$ & $-2.5117\left(0.021^{* *}\right)$ & $X^{2}(2)=7.797\left(0.0203^{* *}\right)$ \\
\hline$\Delta \operatorname{lnMB}$ & $X^{2}(1)=0.01(0.0201)$ & & $\begin{array}{l}-3.9228 \\
\left(0.0009^{* * *}\right)\end{array}$ & $X^{2}(2)=24.1394\left(0.000^{* * *}\right)$ \\
\hline & & $\sum \Delta \ln \mathrm{DCBS}$ & $\mathrm{ECM}_{-1}$ & $\left(\sum \Delta \ln M B, \mathrm{ECM}_{-1}\right)$ \\
\hline$\Delta \operatorname{lnGDP}$ & & $\begin{array}{l}X^{2}(1)=2.1892 \\
(0.139)\end{array}$ & $\begin{array}{l}-2.5117 \\
\left(0.0212^{* *}\right)\end{array}$ & $X^{2}(2)=11.4822\left(0.0032^{* * *}\right)$ \\
\hline$\triangle \operatorname{lnDCBS}$ & $X^{2}(1)=0.95(0.3294)$ & & $\begin{array}{l}1.3483 \\
\left(0.0434^{* *}\right)\end{array}$ & $X^{2}(2)=2.1715\left(0.0376^{* *}\right)$ \\
\hline
\end{tabular}


H. M. A. Simba - E. Çankal 12/2 (2020) 1962-1973

\begin{tabular}{|c|c|c|c|c|}
\hline & & $\sum \Delta \ln \mathrm{DCPS}$ & $\mathrm{ECM}_{-1}$ & $\left(\sum \Delta \operatorname{lnDCBS}, \mathrm{ECM}_{-1}\right)$ \\
\hline$\Delta \operatorname{lnGDP}$ & & $\begin{array}{l}X^{2}(1)=0.00098 \\
(0.975)\end{array}$ & $\begin{array}{l}-2.5116 \\
\left(0.0212^{* *}\right)\end{array}$ & $X^{2}(2)=6.3091\left(0.0427^{* *}\right)$ \\
\hline \multirow[t]{2}{*}{$\triangle \operatorname{lnDCPS}$} & $X^{2}(1)=0.31(0.5804)$ & & $\begin{array}{l}0.129595 \\
(0.8982)\end{array}$ & $X^{2}()=0.5893(0.7448)$ \\
\hline & & $\sum \Delta \operatorname{lnDCFS}$ & $\mathrm{ECM}_{-1}$ & $\left(\sum \Delta \operatorname{lnDCPS}, \mathrm{ECM}_{-1}\right)$ \\
\hline$\Delta \operatorname{lnGDP}$ & & $\begin{array}{l}X^{2}(1)=0.3709 \\
(0.5425)\end{array}$ & $\begin{array}{l}-2.5116 \\
\left(0.0212^{* *}\right)\end{array}$ & $X^{2}(2)=7.0881\left(0.0289^{* *}\right)$ \\
\hline \multirow[t]{2}{*}{$\triangle \operatorname{lnDCFS}$} & $X^{2}(1)=3.96(0.0467)$ & & $-0.5672(0.5772)$ & $X^{2}(1)=4.4018(0.1107)$ \\
\hline & $\sum \Delta \operatorname{lnMB}$ & $\sum \Delta \operatorname{lnDCBS}$ & $\mathrm{ECM}_{-1}$ & $\left(\sum \Delta \operatorname{lnDCBS}, \mathrm{ECM}_{-1}\right)$ \\
\hline$\Delta \operatorname{lnMB}$ & & $\begin{array}{l}X^{2}(1)=1.6572 \\
(0.1980)\end{array}$ & $\begin{array}{l}-3.92283 \\
\left(0.0009^{* * *}\right)\end{array}$ & $X^{2}(2)=16.8253\left(0.0002^{* * *}\right)$ \\
\hline \multirow[t]{2}{*}{$\triangle \operatorname{lnDCBS}$} & $X^{2}(1)=10.1\left(0.001^{* * *}\right)$ & & $1.3483(0.1934)$ & $X^{2}(2)=10.2575\left(0.0059^{* * *}\right)$ \\
\hline & $\sum \Delta \operatorname{lnMB}$ & $\sum \Delta \operatorname{lnDCPS}$ & $\mathrm{ECM}_{-1}$ & $\left(\sum \Delta \operatorname{lnDCPS}, \mathrm{ECM}_{-1}\right)$ \\
\hline$\Delta \operatorname{lnMB}$ & & \begin{tabular}{|l|}
$X^{2}(1)=0.1862$ \\
$(0.6661)$
\end{tabular} & $\begin{array}{l}-3.9228 \\
\left(0.0009^{* * *}\right)\end{array}$ & $X^{2}(2)=15.8285\left(0.0004^{* * *}\right)$ \\
\hline \multirow[t]{2}{*}{$\triangle \operatorname{lnDCPS}$} & \begin{tabular}{|l|}
$X^{2}(1)=0.028$ \\
$(0.8669)$
\end{tabular} & & $\begin{array}{l}0.129595 \\
(0.8982)\end{array}$ & $X^{2}(2)=0.0689(0.9661)$ \\
\hline & $\sum \Delta \ln M B$ & $\sum \Delta \operatorname{lnDCFS}$ & $\mathrm{ECM}_{-1}$ & $\left(\sum \Delta \operatorname{lnDCPS}, \mathrm{ECM}_{-1}\right)$ \\
\hline$\Delta \operatorname{lnMB}$ & & $\begin{array}{l}X^{2}(1)=0.1660 \\
(0.6836)\end{array}$ & $\begin{array}{l}-3.9228 \\
\left(0.0009^{* * *}\right)\end{array}$ & $X^{2}(2)=15.5008\left(0.0004^{* * *}\right)$ \\
\hline \multirow[t]{2}{*}{$\triangle \operatorname{lnDCFS}$} & $X^{2}(1)=3.7\left(0.0557^{* *}\right)$ & & $-0.5672(0.5772)$ & $X^{2}(1)=3.8080(0.1490)$ \\
\hline & $\sum \Delta \ln \mathrm{DCBS}$ & $\sum \Delta \operatorname{lnDCPS}$ & $\mathrm{ECM}_{-1}$ & $\left(\sum \Delta \operatorname{lnDCPS}, \mathrm{ECM}_{-1}\right)$ \\
\hline$\triangle \operatorname{lnDCBS}$ & & $\begin{array}{l}X^{2}(1)=2730.1 \\
\left(0.0^{* * *}\right)\end{array}$ & $1.3483(0.1934)$ & $X^{2}(2)=2742.413\left(0.0000^{* * *}\right)$ \\
\hline \multirow[t]{2}{*}{$\triangle \operatorname{lnDCPS}$} & $X^{2}(1)=0.001(0.9876)$ & & $0.1295(0.8982)$ & $X^{2}(2)=0.0229(0.9886)$ \\
\hline & $\sum \Delta \ln D C B S$ & $\sum \Delta \operatorname{lnDCFS}$ & $\mathrm{ECM}_{-1}$ & $\left(\sum \Delta \operatorname{lnDCFS}, \mathrm{ECM}_{-1}\right)$ \\
\hline$\triangle \operatorname{lnDCBS}$ & & $\begin{array}{l}X^{2}(1)=5.3379 \\
\left(0.021^{* *}\right)\end{array}$ & $\begin{array}{l}1.348367 \\
(0.1934)\end{array}$ & $X^{2}(2)=8.1906\left(0.0167^{* *}\right)$ \\
\hline \multirow[t]{2}{*}{$\triangle \operatorname{lnDCFS}$} & $\begin{array}{l}X^{2}(1)=0.5589 \\
(0.4547)\end{array}$ & & $\begin{array}{l}-0.567296 \\
(0.5772)\end{array}$ & $X^{2}(2)=0.6636(0.7176)$ \\
\hline & $\sum \Delta \operatorname{lnDCPS}$ & $\sum \Delta \operatorname{lnDCFS}$ & $\mathrm{ECM}_{-1}$ & $\left(\sum \Delta \operatorname{lnDCFS}, \mathrm{ECM}_{-1}\right)$ \\
\hline$\triangle \operatorname{lnDCPS}$ & & $\begin{array}{l}X^{2}(1)=0.0189 \\
(0.8906)\end{array}$ & $0.1295(0.8982)$ & $X^{2}(2)=0.0405(0.9799)$ \\
\hline$\triangle \operatorname{lnDCFS}$ & $X^{2}(1)=0.034(0.857)$ & & $-0.5672(0.5772)$ & $X^{2}(2)=0.3634(0.8338)$ \\
\hline
\end{tabular}




\section{H. M. A. Simba - E. Çankal 12/2 (2020) 1962-1973}

Both BM and GDP have a mutual relationship. Whenever there is a good circulation of the BM in the financial system of Tanzania, it creates a positive correlation on the GDP and vice versa. Domestic credit to bank services shows a sign on the GDP of Tanzania. The relationship is the causal unidirectional relationship that moves from DCBS to GDP. The relationship is significant and indicates that DCBS determine the GDP of Tanzania. The extension and improving the DCBS have a positive impact on GDP. Investing in banking and financing sectors will provide growth of GDP. The analysis indicates the causal correlation between GDP and DCPS, and relationship is the unidirectional in which the directional move is from DCPS to GDP. The DCPS is important on GDP of Tanzania, which means that the GDP of Tanzania depends on DCPS. The relationship between DCFS and GDP is the causal unidirectional relationship in which the direction is running from DCFS towards GDP. Thus, GDP depends on DCFS. The DCFS has a huge impact on the GDP of Tanzania. The improvement of finance sectors contributes significantly on GDP in Tanzania. A causal bidirectional relationship between $\mathrm{MB}$ and DCBS has been observed from the analysis; both are dependent on each other. As the MB becoming higher in the financial systems, it leads to expand the rate of DCBS in the financial systems and vice versa. The improvement of these sectors will result in growth of the economic performance in Tanzania. The relationship between MB and CDFS is the causal unidirectional relationship, which runs from the DCFS towards MB, meaning that MB depends on DCFS. The estimation indicates no causal correlation between DCPS and DCFS. The least but last the DCFS has week causal relationship with all the variables. In general, the analysis revealed the bidirectional causal relationship between GDP and FDI in Tanzania. The summary of causal relationship between FDI and GDP has been shown in Table 6.

Table 6: Summary from the Table 4.

\begin{tabular}{|c|c|c|}
\hline Variables & Finance Development & Economic growth \\
\hline$\Delta \operatorname{lnGDP}$ and $\Delta \ln M B$ & & $\begin{array}{l}\text { Economic growth causes } \\
\text { Finance Development } \\
\text { Institutions }\end{array}$ \\
\hline$\Delta \operatorname{lnMB}$ and $\Delta \ln G D P$ & $\begin{array}{l}\text { Finance Development Institutions cause } \\
\text { Economic growth }\end{array}$ & \\
\hline$\triangle \operatorname{lnGDP}$ and $\triangle \ln D C B S$ & & $\begin{array}{l}\text { Economic growth causes } \\
\text { Finance Development } \\
\text { Institutions }\end{array}$ \\
\hline$\triangle \operatorname{lnDCBS}$ and $\triangle \operatorname{lnGDP}$ & $\begin{array}{l}\text { Finance Development Institutions cause } \\
\text { Economic growth }\end{array}$ & \\
\hline$\triangle \operatorname{lnGDP}$ and $\triangle \ln D C P S$ & & $\begin{array}{l}\text { Economic growth causes } \\
\text { Finance Development } \\
\text { Institution }\end{array}$ \\
\hline$\triangle \operatorname{lnGDP}$ and $\triangle \operatorname{lnDCFS}$ & & $\begin{array}{l}\text { Economic growth causes } \\
\text { Finance Development } \\
\text { Institutions }\end{array}$ \\
\hline
\end{tabular}

The results accept the demanding growth hypothesis that represents the economic growth of Tanzania leads the Financial Development Institutions.

\section{Conclusion}

This paper discusses the causal relationship between GDP and the proxy of FDI from 1989 to 2018 examining the causal correlation between FDI and GDP involving four proxies of FDI over GDP. The data analyses are performed by employing the econometric tools such as ADF, PP, ARDL, VECM and Granger causality. The results indicate that the GDP and the FDI are integrated at level and first difference. The FDI and GDP demonstrate cointegration that resulted both in the long run and short run in Tanzania. The results show that economic growth in Tanzania dominates the financial development institutions. The financial development institutions in Tanzania largely depend on economic growth. The findings also justify the demand growth hypothesis. The results show that both FDI and GDP depend on each other. Although the strength of some of the proxies of FDI and GDP seem to be weak, it doesn't mean the proxies of FDI against GDP are weak. The analyses can support the argument that for all intents and purposes GDP leads to FDI and vice versa. 


\section{References}

Akindele, A. L. (2015). Economic Analysis Of Hostel Accommodations In Nigeria Tertiary Institutions: A Case Study Of Federal University Of Agriculture, Abeokuta.

Al-naif, K. L. (2012). Causality relationship between financial development and economic growth in Jordan: Supply-leading and demand-pulling hypotheses test. Middle Eastern Finance and Economics, 16(16), 1000-1009.

Ang, J. B. (2008). A survey of recent developments in the literature of finance and growth. Journal of Economic Surveys, 22(3), 536-576.

Beck, T., Demirgüç-Kunt, A., Levine, R. (2000). A new database on the structure and development of the financial sector. The World Bank Economic Review, 14(3), 597-605.

Bencivenga, V. R., Smith, B. D. (1991). Financial intermediation and endogenous growth. The Review of Economic Studies, 58(2), 195-209.

Calderón, C., Liu, L. (2003). The direction of causality between financial development and economic growth. Journal of Development Economics, 72(1), 321-334.s

Cho, Y. J. (1990). McKinnon-Shaw versus the neostructuralists on financial liberalization: A conceptual note. World Development, 18(3), 477-480.

De Gregorio, J., Guidotti, P. E. (1995). Financial development and economic growth. World Development, 23(3), 433-448.

Demetriades, P. O., Hussein, K. A. (1996). Does financial development cause economic growth? Time-series evidence from 16 countries. Journal of Development Economics, 51(2), 387-411.

Goldsmith, R. W. (1969). Financial structure and development (No. HG174 G57).

Greenwood, J., Jovanovic, B. (1990). Financial development, growth, and the distribution of income. Journal of Political Economy, 98(5, Part 1), 1076-1107.

Herwartz, H., \& Walle, Y. M. (2014). Determinants of the link between financial and economic development: Evidence from a functional coefficient model. Economic Modelling, 37, 417-427.

Gregorio, J. D., Guidotti, P., Végh, C. (1998). Inflation stabilisation and the consumption of durable goods. The Economic Journal, 108(446), 105-131.

Hermes, N., Lensink, R. (2008). Does financial liberalization influence savings, investment, and economic growth? Evidence from 25 emerging market economies, 1973-96. In Financial Development, Institutions, Growth, And Poverty Reduction (pp. 164-189). Palgrave Macmillan, London.

Holmes, S., Kent, P. (1991). An empirical analysis of the financial structure of small and large Australian manufacturing enterprises. Journal of Small Business Finance, 1(2), 141-154.

Jung, W. S. (1986). Financial development and economic growth: international evidence. Economic Development and Cultural Change, 34(2), 333-346.

King, R. G., Levine, R. (1993). Finance and growth: Schumpeter might be right. The Quarterly Journal of Economics, 108(3), 717-737.

Levine, R. (1999). Financial development and economic growth: views and agenda. The World Bank.

Luintel, K. B., \& Khan, M. (1999). A quantitative reassessment of the finance-growth nexus: evidence from a multivariate VAR. Journal of Development Economics, 60(2), 381-405.

Murinde, V., Eng, F. S. (1994). Financial Restructuring and Economic Growth in Singapore/Restructuration Financiere Et Croissance Economique A Singapour. Savings and Development, 225-246.

Odedokun, M. O. (1996). Alternative econometric approaches for analyzing the role of the financial sector in economic growth: Time-series evidence from LDCs. Journal of Development Economics, 50(1), 119-146. 
H. M. A. Simba - E. Çankal 12/2 (2020) 1962-1973

Odhiambo, N. M. (2005). Financial development and economic growth in Tanzania: A dynamic causality test. African Finance Journal, 7(1), 1-17.

Odhiambo, N. M. (2008). Financial depth, savings, and economic growth in Kenya: A dynamic causal linkage. Economic Modelling, 25(4), 704-71

Patrick, H. T. (1966). Financial development and economic growth in underdeveloped countries. Economic Development and Cultural Change, 14(2), 174-189.

Pradhan, R. P., Arvin, M. B., Bahmani, S., Hall, J. H., Norman, N. R. (2017). Finance and growth: Evidence from the ARF countries. The Quarterly Review of Economics and Finance, 66, 136-148.

Reinhart, C., Tokatlidis, I. (2005). Before and after financial liberalization.

Rioja, F., Valev, N. (2004). Finance and the sources of growth at various stages of economic development. Economic Inquiry, 42(1), 127-140.

Schumpeter, J. (1911). The theory of economic development. Harvard Economic Studies. Vol. XLVI.

Shan, J. Z., Morris, A. G., Sun, F. (2001). Financial Development and Economic Growth: an egg-and-chicken problem?. Review of International Economics, 9(3), 443-454.

Tsuru, K. (2000). Finance and growth. Some Theoretical Considerations and a Review of the Empirical Literature," OECD Economics Department Working Papers 228, OECD Publishing.

Waqabaca, C. (2004). Financial Development and Economic Growth in Fiji. Economics Department, Reserve Bank of Fiji. 